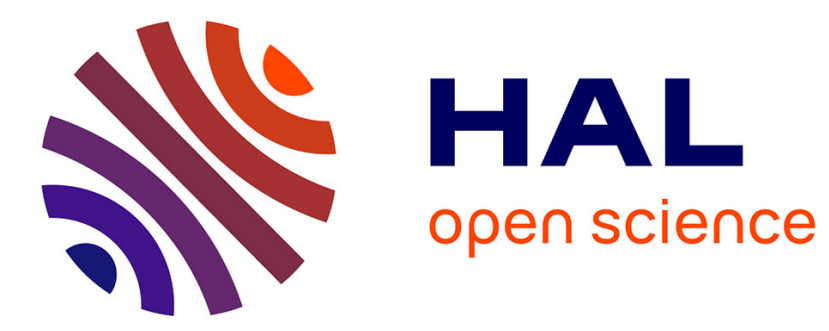

\title{
Assessment of Counter-Measures for Disturbance Management in Manufacturing Environments
}

Volker Stich, Moritz Schröter, Felix Jordan, Lucas Wenger, Matthias Blum

\section{To cite this version:}

Volker Stich, Moritz Schröter, Felix Jordan, Lucas Wenger, Matthias Blum. Assessment of CounterMeasures for Disturbance Management in Manufacturing Environments. IFIP International Conference on Advances in Production Management Systems (APMS), Sep 2017, Hamburg, Germany. pp.449-456, 10.1007/978-3-319-66923-6_53 . hal-01666167

\section{HAL Id: hal-01666167 https://hal.inria.fr/hal-01666167}

Submitted on 18 Dec 2017

HAL is a multi-disciplinary open access archive for the deposit and dissemination of scientific research documents, whether they are published or not. The documents may come from teaching and research institutions in France or abroad, or from public or private research centers.
L'archive ouverte pluridisciplinaire HAL, est destinée au dépôt et à la diffusion de documents scientifiques de niveau recherche, publiés ou non, émanant des établissements d'enseignement et de recherche français ou étrangers, des laboratoires publics ou privés. 


\title{
Assessment of Counter-Measures for Disturbance Management in Manufacturing Environments
}

\author{
Prof. Dr. Volker Stich ${ }^{1}$, Moritz Schröter ${ }^{1}$, Felix Jordan ${ }^{1}$, Lucas Wenger ${ }^{1}$, Matthias \\ Blum $^{1}$ \\ ${ }^{1}$ Institute for Industrial Management at RWTH Aachen University (FIR), Aachen, Germany \\ \{volker.stich, moritz.schroeter, felix.jordan, lucas.wenger, \\ matthias.blum\}@fir.rwth-aachen.de
}

\begin{abstract}
With big data-technologies on the rise, new fields of application appear in terms of analyzing data to find new relationships for improving process understanding stability. Manufacturing companies oftentimes cope with a high number of deviations but struggle to solve them with less effort. The research project BigPro aims to develop a methodology for implementing counter measures to disturbances and deviations derived from big data. This paper proposes a methodology for practitioners to assess predefined counter measures. It consists of a morphology with several criterions that can have a certain characteristic. Those are then combined with a weighting factor to assess the feasibility of the counter measure for prioritization.
\end{abstract}

Keywords: Counter Measures, Deviations, Disturbance Management

\section{Introduction}

The amount of data generated in production companies is continuingly growing. One reason for this development is the advancing integration of system control and measurement utilities within the production, due to new cost-efficient, high-performance information technologies. Whereas the number of applications for isolated optimization problems is continuously growing, the analysis of complex processes as found in production systems require suitable data models representing the real world [1].

The research project BigPro addresses this issue by creating a Big Data driven, proactive disturbance management system, capable of processing various data from the manufacturing environment. Within a platform, data will be analyzed for data patterns that indicate possible disturbances in the production system. The results of the analysis is matched with a set of predefined counter-measures and then forwarded to responsible stakeholders. Additionally, generic counter-measures are proposed, if no specific one is available.

This paper deals with a systematic approach to asses counter measures for disturbances in a manufacturing environment. The remainder of this paper is organized as follows: First, we give a literature overview of existing approaches to disturbance management and classification of measures in Section 2. Next, we introduce the concept of 
the proposed methodology to evaluate counter measure in Section 3 describe the underlying calculation scheme. Finally, we conclude in Section 4 and highlight future work.

\section{$2 \quad$ Literature Review}

Before describing the developed assessment model, the terms of disturbance and deviation in context of manufacturing environments are explained. Furthermore, existing concepts of disturbance management are reviewed.

\subsection{Disturbance variables in operations management}

In manufacturing practice as well as in research the concepts of disturbances and deviations are often used as a synonym. Disturbances interrupt or at least affect a running production or logistics process [2]. Deviations are unexpected differences between the actual and the planned state, which must not lead to failure but could be indicators for disturbances [2, 3].

To measure such disturbances a set of disturbance variables is necessary, which are recorded and observed through time. Disturbance variables are distinguished by their relation to a process, a temporal progress, an impact and a reason [4]. Furthermore, deviation variables are divided into exogenous and endogenous depending on the sphere of influence of the affected company [5]. Research has shown that less than $30 \%$ of disturbances in manufacturing are exogenous [4]. Since the project scope lies on process-related disturbances on the Shopfloor, exogenous disturbances are no longer considered.

\subsection{Disturbance Management}

To cope with the high number of possible deviations in an ever-complex production environment disturbance must be handled systematically. SIMON defines the disturbance management in the context of production control. It is task of the disturbance management to initiate appropriate reactions to significant deviations between logistics aims and conclusion from feedback data [6]. FISCHÄDER extends the definition by considering the purpose of disturbance management from an economical perspective. Therefore, goal of the disturbance management is the minimization of costs of the disturbance itself and the taken measures [7].

The disturbance management consists of three different steps. Firstly a disturbance is indicated by a deviation e.g. of a defined indicator. Secondly, the derivation is analyzed and decided if a counter measure has to be taken. Depending on affected object and type of derivation a corresponding counter measures has to be selected and implemented. Afterwards it is determined, if the measure has been successful and the disturbance is remedied. Otherwise another measure hast to be taken [4, 7]. 
FISCHÄDER's approach focusses on the design of production systems and adaptions of the capacities. Those adaption measures are implemented in several models and directly related to logistics KPIs. Although this is very precise depiction of possible options, it stays on a rather theoretical level [7].

LEITÃo develops a holonic architecture for disturbance management for flexible manufacturing systems. It comprises of holons for resources, maintenance, quality control, products and the supervisor. The chosen approach allows the detection and diagnoses of disturbances. The taken measure is always a re-scheduling of orders under consideration of available resources, which are evaluated by their price, location and reputation. In addition a prediction of disturbances is described [8].

PATTIG and THORHAUER present a disturbance management for rescheduling production orders based on the availability of material and potential factors (machines, equipment and personal). The approach focuses on a methodology for the production control and makes the order release depend on the availability of aforementioned production factors. Disturbances within a production process are not addressed explicitly [9].

MEYER develops a "disturbance variable management", that allows a precise description of disturbances [10]. Measures are stored in a database and linked manually to a disturbance. Thereby the measures mostly are of conceptual character, e.g. doing a 5 Why Analysis or carrying out an FMEA. The measures are linked to the necessary qualification of staff, which is stored separately [11].

\subsection{Systemization of measures in disturbance management}

Disturbance management includes different types of measures to cope with upcoming disturbances. Those haven been classified by several characteristic (see Table 1).

Table 1. Systemization of measures in disturbance management [2]

\begin{tabular}{|l|c|c|c|c|}
\cline { 2 - 5 } \multicolumn{1}{c|}{} & \multicolumn{2}{c|}{ preventive measures } & \multicolumn{2}{c|}{ reactive measures } \\
\cline { 2 - 5 } \multicolumn{1}{c|}{} & analytical & statistical & repulsive & withdrawing \\
\hline cause-related measures & & & & \\
\hline impact-related measures & & & & \\
\hline
\end{tabular}

First of all measures can be classified into preventive and reactive measures [9]. Preventive measures aim at the identification and elimination of possible deviations or disturbances. Whereas analytical approaches can lead to the cause of a disturbance, statistical methods only apply to the observed effects and therefore the impact [2]. Applying preventive measures in most cases is associated with financial expenses and personal expenditures [4]. Therefore, it has to be clearly determined, if the consequences of the disturbance justifies the costs or if it is more favorable to react. Furthermore, preventive measures should only be taken when a possible scenario concluding of description of the disturbance and the time is available [4].

On the other hand, a measure taken after the disturbance has occurred is called reactive measure. Compared to preventive measures the effectivity is decreased. Nevertheless, these can be sensible when the costs of remedy are lower than the cost effects of 
the disturbance or the disturbance cannot be predicted at all or with the necessary precision. Reactive measures can be divided further into repulsive measure, which aim for a remedy or decrease of impact and so-called withdrawing measures when the only option is to reduce the spread of the effects. [4]. Furthermore, the measures can be classified into cause-related and impact-related. Whereas the former aim for the remedy, the latter can only reduce the effects [4].

\subsection{Conclusion}

Whereas the proposed systemization for measures allows the assignment of any realworld measure to one of the fields, the presented approaches lack a detailed evaluation concept. This can be explained with the strong focus on production planning and control [9] as well as supply chain planning problems [2, 7]. In these areas, the impact of single measures on indicators often is hard to describe. Another approach deals with the implementation of several solution concepts [12]. For the proposed disturbance, management based on big data an assessment for specific and even more general measures is necessary.

\section{Assessment of Counter-Measures for Disturbance Management in Manufacturing Environments}

BigPro focusses on disturbance management in manufacturing environments relying on BigData analytics. Therefore, several information sources on the shop floor are connected to a universal messaging bus. Predefined patterns, which are supplemented during operation, lead to error messages. A combination of error messages then is mapped to a disturbance. Based on a list of possible failures derived from FMEA and other process analytics approaches possible counter measures are selected. In many cases, there is more than one counter measure, depending on the level of criticality or only a few can be initiated, since not all prerequisites are met. For a further description of the platform and the integration of the counter-measures see [13].

In the following, the morphology to describe counter measures is presented before explaining the assessment methodology in detail. The application is shown with a real world example from an industrial partner.

\subsection{Morphology of counter measures}

To assess counter measures, a set of description criterions has been developed. The research follows a desk research approach, combining several aspects of existing work in disturbance management. The results are presented in Table 2 and explained in detail in chapter 3.3. 
Table 2. Relevant criterions to asses counter measures in BigPro disturbance management

\begin{tabular}{|c|c|c|c|}
\hline $\mathbf{i}$ & criterion & explanation & ref. \\
\hline 1 & duration of measure & time from detection until recovery & {$[4]$} \\
\hline 2 & cost of measure & necessary expenses to perform the measure & {$[14]$} \\
\hline 3 & $\begin{array}{c}\text { presumed/actual impact } \\
\text { of measure }\end{array}$ & $\begin{array}{c}\text { impact of the measure in terms of fixing the symp- } \\
\text { toms or the reason }\end{array}$ & {$[15]$} \\
\hline 4 & standardization of m. & $\begin{array}{c}\text { current degree and quality of documentation to } \\
\text { perform the measure }\end{array}$ & {$[4,11]$} \\
\hline 5 & $\begin{array}{c}\text { organizational } \\
\text { escalation level }\end{array}$ & $\begin{array}{c}\text { implementation level of the measure (e.g. ma- } \\
\text { chine, plant, supply network) }\end{array}$ & {$[16]$} \\
\hline 6 & $\begin{array}{c}\text { degree of qualified staff } \\
\text { available }\end{array}$ & $\begin{array}{c}\text { Share of staff, which is qualified to perform the } \\
\text { counter measure }\end{array}$ & {$[11]$} \\
\hline
\end{tabular}

\subsection{Mathematical model to assess counter measures}

To find appropriate measures and to bring them in an order, a numerical calculation is necessary. Table 3 provides an overview of the proposed evaluation scheme to asses counter measures in disturbance management.

Table 3. Evaluation scheme for characteristics of measures

\begin{tabular}{|c|c|c|c|c|c|c|}
\hline \multirow{2}{*}{ i } & \multirow{2}{*}{ criterion } & \multicolumn{5}{|c|}{ characteristic c } \\
\cline { 3 - 7 } & $\mathbf{0}$ & $\mathbf{1}$ & $\mathbf{2}$ & $\mathbf{3}$ & $\mathbf{4}$ \\
\hline no. & description & $\begin{array}{c}\text { not } \\
\text { feasible }\end{array}$ & $\begin{array}{c}\text { partly } \\
\text { feasible }\end{array}$ & $\begin{array}{c}\text { mainly fea- } \\
\text { sible }\end{array}$ & $\begin{array}{c}\text { very } \\
\text { feasible }\end{array}$ & optimal \\
\hline
\end{tabular}

Each criterion $i$ is subdivided into five different characteristics $c$. Each possible characteristic is represented by a value, starting from 0 for not feasible at all up to 4 representing the optimal condition. To adapt the criterions to disturbance-specific cases, a simple weighting formula is introduced.

$$
\mathrm{M}=\frac{\sum_{i=1}^{\mathrm{F}} \omega_{i} \cdot c_{i}}{\sum_{i=1}^{F} \omega_{i}}
$$

Let $M$ be the priority of the measure, $F$ the number of features (6) $w_{i}$ a weighting factor within a range from 0 (irrelevant) to 4 (highly relevant) and $c_{i}$ the valuation of the feasibility of the feature $i$. The minimum of $\mathrm{M}$ can be 0 , whereas the maximum is 4 . In the following exemplary characteristics are assigned to any criterion.

\subsection{Explanation and application}

The developed morphology and evaluation scheme was applied at an industrial partner of the research project. The use case deals with an assembly of pedelec carts with manual assembly tasks. The disturbance is a scratched type plate provided by a supplier and 
labeled in-house. Table 4 provides an overview of possible characteristics, which are explained in detail below.

Table 4. Possible criterions with characteristics derived from the industrial use case

\begin{tabular}{|c|c|c|c|c|c|c|}
\hline \multirow{2}{*}{$\mathbf{i}$} & \multirow{2}{*}{ criterion } & \multicolumn{5}{|c|}{ characteristics $\mathbf{C}_{\mathbf{i}}$} \\
\hline & & $\mathbf{0}$ & 1 & 2 & 3 & 4 \\
\hline 1 & duration & $>1$ month & $\begin{array}{l}1 \text { week - } \\
1 \text { month }\end{array}$ & $\begin{array}{l}1 \text { day - } \\
1 \text { week }\end{array}$ & $\begin{array}{c}1 \text { hour - } \\
1 \text { day }\end{array}$ & $<1$ hour \\
\hline 2 & costs $[€]$ & $>100.000$ & $>10.000$ & $>1.000$ & $>100$ & $<100$ \\
\hline 3 & $\begin{array}{l}\text { impact of } \\
\text { measure }\end{array}$ & none & $\begin{array}{c}\text { dev. impact } \\
\text { decreased }\end{array}$ & $\begin{array}{c}\text { dev. impact } \\
\text { eliminated }\end{array}$ & \begin{tabular}{|c|} 
dev. impact re- \\
solved, cause \\
decreased \\
\end{tabular} & $\begin{array}{c}\text { Cause } \\
\text { eliminated }\end{array}$ \\
\hline 4 & $\begin{array}{c}\text { standardiza- } \\
\text { tion of m.r }\end{array}$ & none & $\begin{array}{c}\text { roughly } \\
\text { documented }\end{array}$ & $\begin{array}{l}\text { moderately } \\
\text { documented }\end{array}$ & $\begin{array}{c}\text { well } \\
\text { documented }\end{array}$ & \begin{tabular}{|c|} 
fully docu- \\
umented \\
\end{tabular} \\
\hline 5 & $\begin{array}{c}\text { organiza- } \\
\text { tional esca- } \\
\text { lation level }\end{array}$ & $\begin{array}{l}\text { Supply } \\
\text { Chain }\end{array}$ & Plant & Shopfloor & Machine group & work place \\
\hline 6 & $\begin{array}{l}\text { coverage } \\
\text { rate of quali- } \\
\text { fied staff }\end{array}$ & $0 \%$ & $<5 \%$ & {$[5 \% ; 25 \%)$} & [25 \%; $50 \%]$ & $>50 \%$ \\
\hline
\end{tabular}

For the presented approach, the duration of measure is defined as the timespan between the observation of a disturbance and the (noticeable) effect of the initiated counter-measure. Since the disturbance management foremost handles short-term disturbances, a short duration of measure is desired. A long time span indicates mid- or long-term measures such as process redesign. The given characteristics have to be adapted to the company's requirements. A duration of less than an hour can lead to significant waste and is not acceptable, whereas other processes allow a relative long time for corrections.

As mentioned before, the disturbance management deals with the minimization of costs [7]. Therefore, the trade-off is between costs of the disturbance and costs of a measure. It is up to the company to define the exact bounds of the characteristics; the given values only serve as an example and are derived from the use-case.

The impact of the measure relates to the effect of the measure on the deviation variable or the cause of the disturbance. The more sustainable, the higher the stage. Examples for the solely elimination of the effects of a deviation is the implementation of a $100 \%$ quality control. Hereby it is ensured, that no waste is processed any further without addressing the causes. The reason for the fault remains unknown at the first glance and needs further examination.

For an efficient and effective disturbance management, counter-measures should be standardized and therefore documented in a way that allows employees to take the best actions possible. This accounts for extensive measures, especially [4]. It is further distinguished between certain degrees of documentation, e. g. it has to be checked, if 
the documentation consist of visualizations like flow diagrams, illustrations etc. or is only a short summary and difficult to comprehend if never done before.

A measure can either relate on a certain work place (e.g. a disturbed machine with a defined problem state and solution) or affect the whole supply chain. This is taken into account with the organizational escalation level. Later oftentimes requires additional efforts and resources. Therefore, the former option (a local solution) is preferred in any case the desired level impact of measure (see criterion 3) can be achieved.

Whereas the documentation of a feasible solution is always the best option, the desired resolution can only be achieved if qualified staff is available [11]. This requires an appropriate personal capacity planning and a certain degree of qualified employees. The characteristics therefore take into account the mean degree of qualified personal available to fix the considered disturbance.

Table 5 shows a possible application after setting the characteristics of counter measures within a workshop with the industrial use case partner. Weightings have been set as well as the specific value for each criterion. In the result, the measure scores at 1.7 out of 4 and therefore is comparable to other measures for the specific or similar disturbances.

Table 5. Exemplary calculation of general feasibility of a measure

\begin{tabular}{|c|c|c|c|c|c|c|c|c|}
\hline \multirow{2}{*}{$\mathrm{i}$} & \multirow{2}{*}{ criterion } & \multicolumn{3}{c|}{ characteristic } & \multicolumn{2}{c|}{ weighting } & \multirow{2}{*}{} \\
& & $\mathbf{0}$ & $\mathbf{1}$ & $\mathbf{2}$ & $\mathbf{3}$ & $\mathbf{4}$ & $\mathbf{W}$ & $\mathbf{c}_{\mathbf{i}} \cdot \mathbf{W} \mathbf{i}$ \\
\hline 1 & duration of measure & & & & & & 3 & 3 \\
\hline 2 & costs of measure [€] & & & & & & 4 & 8 \\
\hline 3 & impact of measure & & & & & & 2 & 2 \\
\hline 4 & standardization of measure & & & & & & 3 & 9 \\
\hline 5 & org. escalation level & & & & & & 1 & 3 \\
\hline 6 & coverage rate of qualified staff & & & & & 4 & 4 \\
\hline \hline
\end{tabular}

\section{Conclusion and Outlook}

The paper presents an approach to assess pre-defined counter-measures. Therefore, characteristics from existing approaches have been combined. The weighting component enables companies to specify borders in context of their processes and requirements. Once the characteristics for each criterion are defined, new measures can easily be evaluated and connected to newly occurring disturbances. This is a crucial step to increase the automation level of the desired disturbance management. Further research is needed for finding ideal types for several kinds of measures (e.g. logistics measures, maintenance tasks, production re-scheduling). 


\section{Acknowledgements}

The BigPro project is funded by the German Federal Ministry of Education and Research (Project number 01|S14011A-I), in the context of the operational program ICT 2020 -Research for Innovation. The project will end in November 2017.

Special thanks go to: Auto Heinen GmbH, Asseco Solutions AG, Cognesys GmbH, i2solutions GmbH, Robert Bosch GmbH, Software AG, FZI Forschungszentrum Informatik, Werkzeugmaschinenlabor der RWTH Aachen.

\section{References}

1. Stich, V.; Jordan, F.; Birkmeier, M.; Oflazgil, K.; Reschke, J.; Diews, A.: Big Data Technology for Resilient Failure Management in Production Systems. In: Advances in production management systems. Innovative production management towards sustainable growth;APMS 2015, Tokyo, Japan, September 7-9, 2015

2. Meyer, M.: Logistisches Störungsmanagement in kundenverbrauchsorientierten Wertschöpfungsketten. Shaker, Aachen 2007.

3. Schmitz, S.; Krenge, J.: Big Data im Störmanagement. In: Tagungsband '44. Jahrestagung der Gesellschaft für Informatik, Informatik 2014, Big Data - Komplexität meistern"

4. Heil, M.: Entstörung betrieblicher Abläufe. Dt. Univ.-Verl.; Gabler, Wiesbaden 1995.

5. Bauer, C.-O.; Warnecke, H.-J.: Instandhaltungsmanagement. TÜV Rheinland, Köln 1992.

6. Simon, D.: Fertigungsregelung durch zielgrössenorientierte Planung und logistisches Störungsmanagement. Springer, Berlin, 1995.

7. Fischäder, H.: Störungsmanagement in netzwerkförmigen Produktionssystemen. 1. Aufl. DUV 2007.

8. Leitão, P.: A holonic disturbance management architecture for flexible manufacturing systems. In: International Journal of Production Research 49 (2011) 5, S. 1269 - 1284.

9. Patig, S.: Flexible Produktionsfeinplanung mit Hilfe von Planungsschritten. Lang, Frankfurt am Main 2001.

10. Knüppel, K.; Meyer, G.; Nyhuis, P.: A Universal Approach to Categorize Failures in Production. In: International Journal of Mechanical, Aerospace, Industrial, Mechatronic and Manufacturing Engineering 8 (2014) 2, S. 24 - 28.

11. Meyer, G.: [Whitepaper] Schlussbericht zu dem IGF-Vorhaben StöGröM - Nachhaltiges Störgrößenmanagement in produzierenden KMU, Hannover, Leibniz Univ. 2015.

12. Meyer, G.; Knüppel, K.; Möhwald, H.; Nyhuis, P.: Kompetenzorientiertes Störgrößenmanagement. In: Productivity Management 19 (2014) 1, S. 15 - 18.

13. Stich, V.; Oflazgil, K.; Schröter, M.; Reschke, J.; Jordan, F.; Fuhs, G.: Big data implementation for the reaction management in manufacturing systems. In: 2015 XXV ICAT. Proceedings : October 29-31, 2015, Sarajevo, Bosnia and Herzegovina. IEEE, Piscataway, NJ 2015, S. 1 - 6.

14. Rochau, P.: Störung unerwünscht. Mit Störgrößenmanagement den Wirkungsgrad im Unternehmen ermitteln. In: Qualität und Zuverlässigkeit 44 (1999) 2, S. 200 - 203.

15. Brüggemann, H.; Bremer, P.: Grundlagen Qualitätsmanagement. Springer Vieweg, Wiesbaden 2015.

16. Gerst, D.; Heinen, T.; Nyhuis, P.; Pachow-Frauenhofer, J.; Schmidt, M.; Wiendahl, H.-P.; Wriggers, F.: Grundlagen der Produktionslogistik. In: Handbuch Logistik. Hrsg.: D. Arnold; A. Kuhn; K. Furmans; h. Isermann; H. Tempelmeier. 3. Auflage. Springer, Berlin 2008, S. $295-370$. 